\title{
Culture and Conversation: Rethinking Brown v. Board of Education a Postponed Commitment to Educational Equality
}

\author{
Jerell B. Hill ${ }^{1}$ \\ ${ }^{1}$ School of Education, Pacific Oaks College, Pasadena, CA, USA \\ Correspondence: Jerell B. Hill, School of Education, Pacific Oaks College, Pasadena, CA, USA. E-mail: \\ jhill1@pacificoaks.edu
}

Received: January 3, 2021 Accepted: February 4, 2021 Online Published: February 9, 2021

doi:10.5539/jel.v10n2p37 URL: https://doi.org/10.5539/jel.v10n2p37

\begin{abstract}
The Brown v. Board of Education (1954) decision was a significant change in social justice and human rights. There is ongoing debate about public education not as a private commodity but as a public good that must be made available on equal terms. Recently, schools are entering an era of second-generation segregation. Poor outcomes, language acquisition programs preventing access to college-readiness courses, and teacher quality are causes for concern. Research on second-generation segregation found that African-American children experience lower rates of academic achievement than their White peers. This was a case study analysis to investigate the impact of teacher preparation and culturally relevant practices related to educational opportunities. The results hold implications on misconceptions of educational improvements for Black children and identify the need to increase cultural responsiveness and an intentional focus on students' assets and needs.
\end{abstract}

Keywords: second-generation segregation, cultural responsiveness, equality of opportunity, critical race theory

\section{Introduction}

In-depth conversations on diversity, equity, and inclusion remain necessary. Segregation is not only separating races; it is also social isolation and isolation from educational opportunities, including language acquisition. Mistrust, social distance, and alienation create extreme resentment, making it impossible to desegregate schools and communities effectively. Many students are being educated through second-generation segregation (Mickelson, 2001, 2015). Meier and colleagues (1991) offered a definition that second-generation segregation is the educational opportunities that are tracked racially within schools based on the grouping of the core academic subjects (reading, science, math and history) during the 6-12 grades. On the other hand, PreK-5th grades, second generation segregation starts with special education identification through psycho-educational assessments and GATE (Gifted and Talented Educations) placements.

Given this opportunity and recalling my experiences as a student, teacher, and school district administrator, I wanted to reflect on one of the most significant cases in history. I understood the different facts and different local conditions that challenge communities' implementation of desegregation plans. Being a student, a teacher and an administrator in those public schools I have firsthand experience within that environment. Furthermore, recognizing the commonality of the legal questions regarding racial discrimination, I thought about the remarks of Chief Justice Warren: "Today, education is a principal instrument in awakening children to cultural values, in preparing them for later professional training, and in helping them adapt and adjust to their environment" (Brown v. Board of Education, 347 U.S. 483, 1954). Also, "Education is perhaps the most important function of state and local governments. Compulsory school attendance laws and the great expenditures for education both demonstrate our recognition of the importance of education to our democratic society" (Brown v. Board of Education, 347 U.S. 483, 1954) Fully realizing this sentiment requires the public to take responsibility and accurately perform and maintain the requirements (Reardon \& Owens, 2014). Moreover, there is a need for effective teachers and systems and for gradual adjustments from existing systems of inequality that continue to operate with intense levels of uncertainty.

Theoretically, solutions are available. However, the right course of action to advance integration efforts requires reflective practice and social cooperation from all who participate. This is not to devalue the decision or criticize the work of others. However, the Brown (1954) decision highlighted a sincere aspiration to change the lives of the oppressed. It established a baseline for addressing systems of inequality and injustice in our institutions. 
Additionally, one cannot expect Brown's provisions to end all multicultural dispositions in society or measure the disadvantages that have occurred since this arrangement of social cooperation without further interpretation. Racial disparities extend beyond ethnicity. Questions remain regarding whether the court should have used its equity powers to ensure implementation of a desegregation plan with deliberate speed by appointing a committee to oversee teacher training, student-teacher ratios, and facilities.

From my experience as a student, teacher, and administrator, I believe there is a second-generation segregation occurring, and it intersects with isolation. The persistent high levels of poverty that are being captured on the figure below demonstrates the disparities between Black students as compared to other ethnicities. Also forms of second-generation segregation has implication of providing students with a certain level of a disgraced education based on poverty (Jensen, 2009) and social class, which magnifies the need for more conversation and reconciliation (Gorski, 2018; Hess et al., 2019). Although the Brown decision was issued 60-plus years ago, disparities still exist.

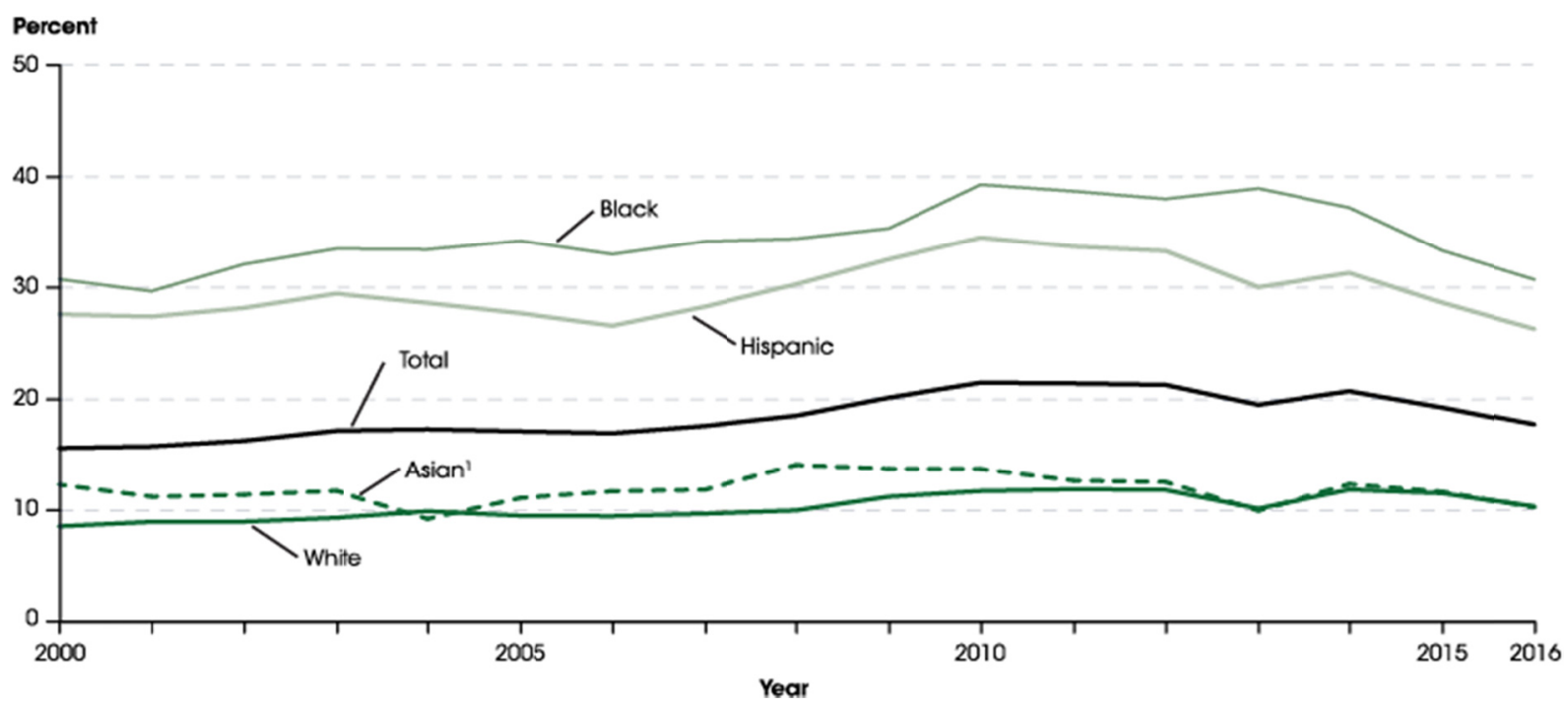

Figure 1. Annual poverty levels

Source: U.S. Department of Commerce, 2017.

The purpose of this exploratory case study is to revisit the Brown (1954) decision in light of contemporary second-generation segregation. The aim is to investigate the impact variables of teacher preparation (ability and achievement) through Lewin's (1936) theory that behavior is a result of the person and the environment: $\mathrm{B}=f$ (PE) (p. 12). The paper sought to address the question of whether White teachers' lack of preparation to teach diverse student populations dilutes African-American children's education. If so, this lack of preparation could have a significant impact on students' educational experiences. The misconceptions about educational improvements for African-American children potentially identify a need to increase cultural responsiveness by intentionally focusing on students' assets and needs. Figure 2 outlines the achievement gap between Black and White students further indicating issues that connecting races and educational outcomes. As mentioned earlier second-generation segregation manifest in the core subject areas of (math reading, language arts and science) the figure below shows the trends in math and reading over a 41-year span. 


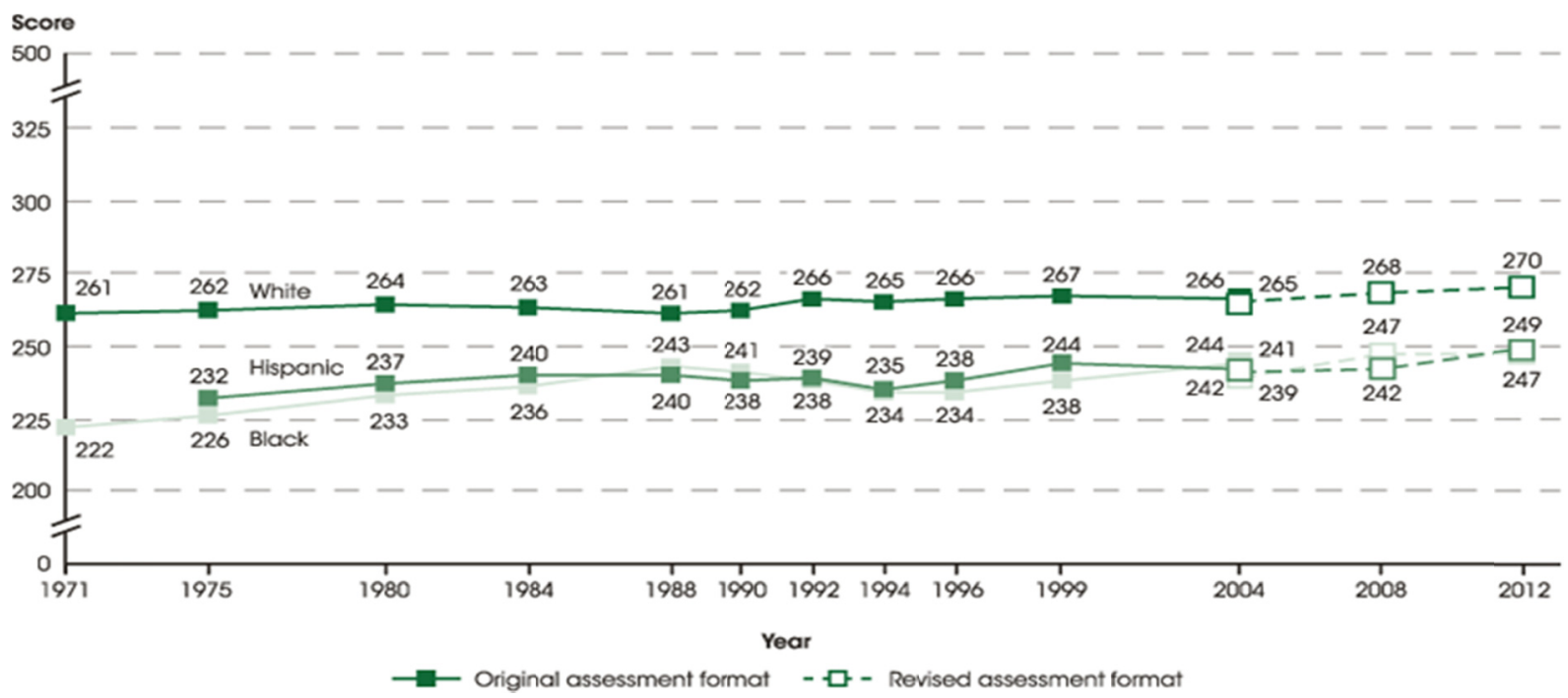

Figure 2. Academic achievement disparities

Source: Nation Center for Educational Statistics, 2013.

Despite the limitations of this subjective approach to situational taxonomies, defined as situations that permit explicit behavior (Gibson, 1977), they establish the foundation for an investigation of the learning environment. The paper contributes to the field because complex problems require continued exploration and investigation of topics like justice and fairness (Rawls, 1971), multicultural education (Howard, 2010), teacher preparation, and student achievement. This paper seeks to shed light on some of the potential causes of missed educational opportunities.

\section{Background}

During a Black History Month celebration in 2020, a panel was convened on the Spangler v. Pasadena City Schools (1976) case to pay tribute to the Brown v. Board of Education (1954) decision. We panelists were asked to provide an explanation of the Brown decision's connections to the Spangler case. Secondly, we were asked what programs, practices, and policies should be implemented to promote student success. The decision was one of the significant milestones in the course of social justice rights and human rights.

Discussions about race are uncomfortable and complicated at times, yet the debate over equality of educational opportunities continues. For example, according to Rosenthal (1957), the National Educational Association (NEA) reported that better results can be obtained when Black students are taught by Black teachers in their own school (DuBois, 1935). When a credible source verifies informed knowledge, an inherited outlook can be perpetuated through the ages.

Beyond segregation, isolation from educational opportunities creates greater disparities and adverse outcomes for African-American children. The primary connection between the cases is a need for an effective desegregation plan. Specifically, Brown (1954) and Spangler (1976) both noted different local conditions and circumstances. The commonality across the U.S. is non-compliance regarding full integration. The Spangler (1976) case is heroic to some (Walker, 2018), as it entailed taking on a social justice mission to ensure desegregation across the United States. Since schools were being unconstitutionally segregated, in Spangler v. Pasadena City Board of Education (1976), the district court ordered school officials to eliminate segregative state action affecting three components of the school system: staff assignments, hiring and promotion, and facility location. Willingness to speak up against the delayed implementation of the Brown decision, along with showing a deep concern for the lack of racial balance, is noteworthy. The Spangler (1976) case established the foundation for the phenomenon that persists in several communities today. The table below illustrates the cases and precedents related to ending segregation. 
Table 1. Legal pathways to end segregation

\begin{tabular}{|c|c|}
\hline Court Case & Legal Matter or Precedent \\
\hline Murray v. Maryland (1937) Maryland Supreme Ct. & $\begin{array}{l}\text { The Maryland Supreme Court forced Maryland to admit Donald Murray to its law } \\
\text { school. Two strategies often employed to avoid admitting Blacks were rejected: 1) } \\
\text { establishing new academic programs at Black colleges, and 2) subsidizing out-of-state } \\
\text { tuition for Black students. }\end{array}$ \\
\hline Gaines v. Canada (1938) U.S. Supreme Court & $\begin{array}{l}\text { Gaines applied to Univ. of Missouri law school. The court supported the Murray } \\
\text { precedent, ordering the admission of Gaines. Missouri's out-of-state tuition subsidies } \\
\text { were rejected, but the Court allowed the state to open an "equal" law school at Lincoln } \\
\text { Univ. (for Blacks). }\end{array}$ \\
\hline Sipuel v. Oklahoma State Board of Regents (1948) & The Oklahoma Supreme Court gave the University three choices: 1) admit Ada Sipuel, \\
\hline U.S. Supreme Court & $\begin{array}{l}\text { 2) immediately open a Black law school, or } 3 \text { ) close the White school until a Black } \\
\text { one was opened. The University chose to establish a makeshift law school, which was } \\
\text { upheld by the U.S. Supreme Court. }\end{array}$ \\
\hline Sweatt v. Painter (1950) U.S. Supreme Court & $\begin{array}{l}\text { Heman Sweatt fought his assignment to Texas' makeshift law school for Blacks. The } \\
\text { court finally found these alternate schools grossly inadequate and in violation of the } \\
\text { equal portion of 'separate but equal.' This ruling reversed Sipuel in which Oklahoma's } \\
\text { separate school was upheld. }\end{array}$ \\
\hline $\begin{array}{l}\text { McLaurin v. Oklahoma (1950) U.S. Supreme } \\
\text { Court }\end{array}$ & $\begin{array}{l}\text { District Court ordered the University of Oklahoma to admit McLaurin to graduate } \\
\text { school. Instead of setting up a makeshift school, Oklahoma maintained segregation by } \\
\text { isolating him while on campus. The court intervened: he must receive the same } \\
\text { treatment as students of other races. }\end{array}$ \\
\hline $\begin{array}{l}\text { Parker v. Delaware (1950) Delaware State Court } \\
\text { (Chancery Court) }\end{array}$ & $\begin{array}{l}\text { A Delaware Chancery Court judge ordered the University of Delaware to admit } \\
\text { several Negro plaintiffs, finding the "colored" colleges in the state to be grossly } \\
\text { inferior. This was the first court-ordered integration of a state-financed institution of } \\
\text { higher education in America. }\end{array}$ \\
\hline
\end{tabular}

Note. Adapted from Kluger, 1976.

The areas of staff assignment, hiring, and promotion lend themselves to the disgraceful education that students receive in contemporary segregated schools: second-generation segregation. For example, when highly skilled teachers elect to teach in affluent areas, novice teachers are assigned to high-needs areas with larger class sizes and fewer resources (Oakes, 2005; Irvine, 2003; Marzano, 2009). In addition, facility location has a significant impact on a community, and the poverty influences attendance, and, ultimately, funding. Exposure to concentrated disadvantage can have detrimental effects on children and their future trajectories (Hess et al., 2019).

Another concern is that teachers shoulder immense pressure and are responsible for the preparation of the nation's future, leading to heavy scrutiny and high political exposure when their performance is mediocre (Goldstein, 2015). There are many consequences when society overlooks the situation. With that being said, the reasons are not simplistic. Bittia and colleagues (2015) assert that significant differences in education quality and quantity during the formative years constitute inequalities that potentially launch students to insurmountable failure levels in their college years.

\section{Methodology}

The cases that followed Brown carried implications of positive immunity while ending discrimination at public institutions. Positive immunity is the right against legal discrimination implying inferiority in civil society, lessening the security of rights others enjoy (Strauder v West Virginia, 100 U.S. 303, 1880). Phenomenology is both a philosophical and theoretical approach premised on a concept of experience as well as a research methodology consistent with this theoretical framework. Phenomenology is an approach to conceptualize and study people's experience, specifically African-American students with consistent philosophical foundations (Giorgi, 1994). To establish what qualifies a qualitative scientific investigation as phenomenological, Giorgi (1997) pinpointed that the distinctive features of phenomenological research are to "employ (1) description (2) within the attitude of the phenomenological reduction, and (3) seek the most invariant meanings for a context" (p. 235) The purpose of this exploratory case study is to revisit the Brown (1954) decision in light of second-generation segregation to understand the impact variables of teacher preparation. An exploratory case study was selected because issues defined as "not simple and clean but intricately wired to political, social, historical, and especially personal contexts" (Stake, 1995 p. 17) are necessary to guide research and develop frameworks (Baxter \& Jack, 2008). The researcher used public records, observations, and archival interview data. 
The analysis occurred by categorical aggregation and direct interpretation (Yin, 2003). The collection and analysis of the archival records and observational experiences could provide possible improvements in teacher preparation, cultural responsiveness, and understanding of the phenomenon of second-generation segregation. Building on the body of prior work (Ladson-Billings,1995; Mickelson, 2001; Banks, 1994; Lewin, 1936; Bandura, 1982; Darling-Hammond, 2010; Howard, 2010; Gay, 2000), the figure below gives a description that amplifies the issues in education and connects the policies and structures that widens the achievement gap as a result of the factors that influence second-generation segregation.

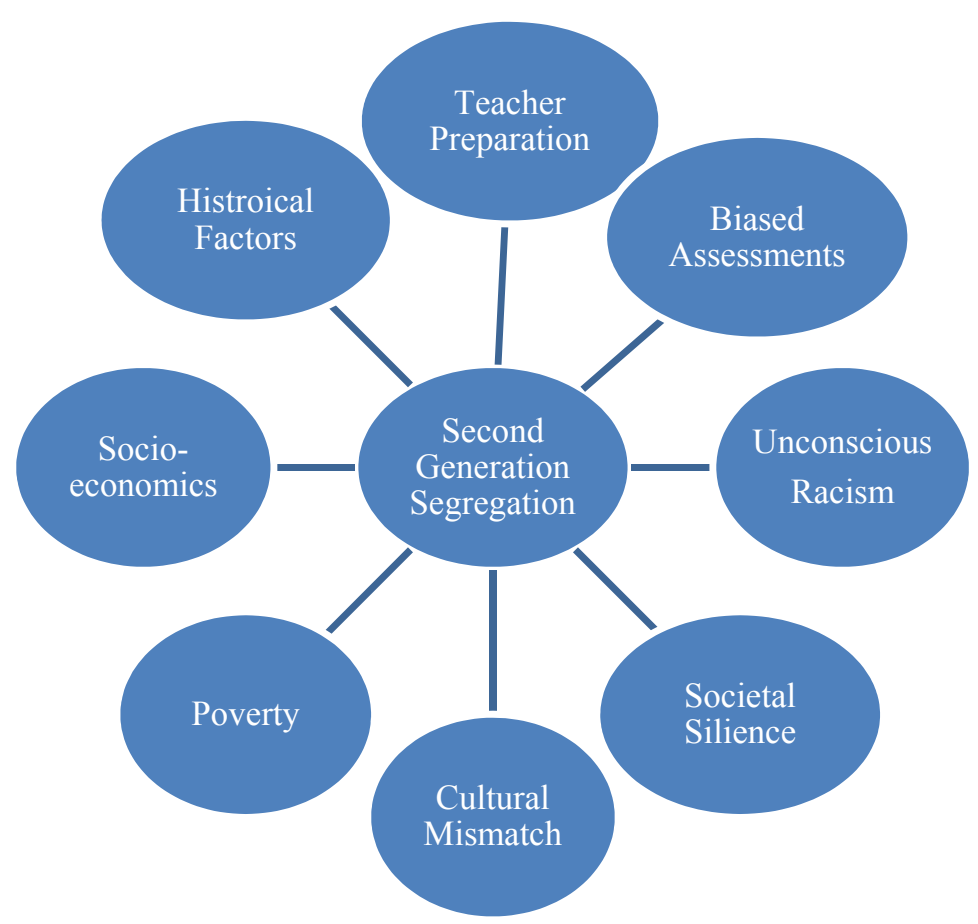

Figure 3. Factors that influence second generation segregation

\section{Results}

\subsection{The Integration Process}

The results demonstrated school reform efforts have opportunities to initiate the integration process and support teachers with training and preparation when the power and decision-making are shared to fully integrate the educational system. Achievement gaps and disparities continue to persist based on resource allocations. Attorney Paul E. Wilson (1953) wrote a letter to the attorney general's office in anticipation of the ruling finding segregated facilities unconstitutional. The letter suggests that the board of education appeared to be making plans for integration. Nonetheless,

The contracts of a number of colored teachers were not renewed last Spring, and the reason given was in the event segregated schools were no longer possible, the board did not feel that a majority of White parents in Topeka would be willing to have their children in classes conducted by a negro teacher. (Wilson, 1953, p. 1)

During an interview, Jackson (1991) recalled living in Topeka at the time of Brown (1954). Jackson acknowledged the efforts of White teachers at the elementary school, trying to integrate Black children into the school and allow them to participate in learning activities. In contrast, her own children experienced racial segregation and unwelcoming environment in junior high school. The shift in behavior and environment was based on the person/s associated with the function, which confirms Lewinian (1936) theory.

Integrating schools and maintaining teacher quality posed challenges. Many Black teachers with advanced degrees opposed integration because it caused economic problems and damaged their self-concept (White \& Parham, 1990). Walker (2018) reviewed the archives of Dr. Horace Tate and described Black teachers as opposed to desegregation because they would lose control over what they taught and feared demotion despite 
holding advanced degrees. School consolidations tend to influence a competitive job market, and the racial tensions made integration of the teaching profession challenging. Walker (2018) affirmed the economic shifts and she implied that many of the local governments and school boards made the teacher selection criteria and the policies around hire and promotion within specific counties further establishing situational poverty due to the terms of the desegregation of schools. Moreover, as noted in her findings, the integration efforts were considered to be "outergratation" meaning that Black students and teachers needed to integrate into White schools and Whites did not have to integrate into Black communities even though they successful built over 259 schools in 103 counties in Georgia. The liquidation of things started in their communities does not indicate the efforts to authentically plan integration efforts. The sharing of power did not seem to be the case and gave more Black educators suspicion regarding the integration of schools. Walker (2018) refers to this as "Dismantling all of the organizational structures and pedagogical percepts of black educators seem to be the price for the Supreme Court decision intended to eradicate inequality, and it was wrong" (p. 8). On the other hand, teacher preparation programs and schools were ill-prepared (Orfield \& Eaton, 1996; Fairclough, 2004; Kluger, 1976; Walker, 2018; Patterson, 1972; Farley et al., 1980). Combined with housing discrimination redlining (Ferri \& Connor, 2005; Frankenberg et al., 2019). African-American professional was relegated to new areas and began exploring new economic opportunities in politics. In fact, some principals of segregated schools re-assigned to lessor roles within schools (i.e., bus attendant, custodian, and yard supervisor) (Walker, 2018). The lack of a cultural orientation (Rogoff, 2003) exposed some the integration challenges. The figure below outlines the approval rating of the Brown (1954) Decision and how initial stages of the integration of the schools were less favorable according to public opinion. The fear that the students would not receive the same quality education (Walker, 2018) troubled Black teachers the most and they voiced their concerns about being excluded from the curriculum decisions. The social capital was damaged in their community and the level of uncertain caused additional calamities.

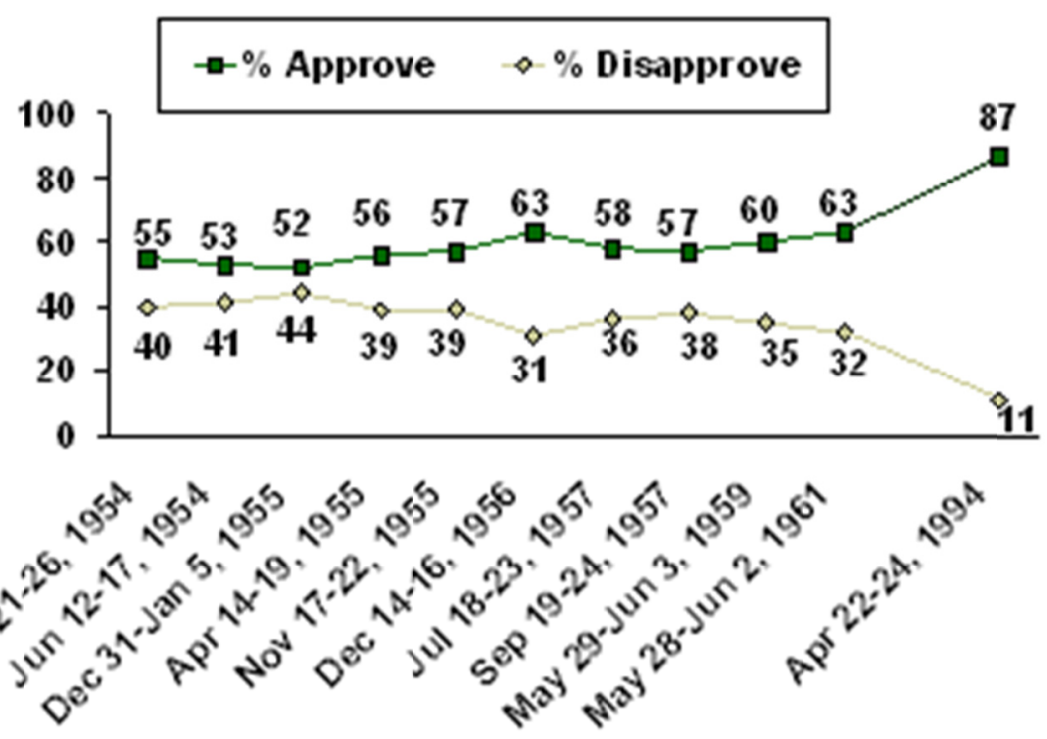

Figure 4. Favorability rates of school integration

Source: Carroll, 2014.

Administrative difficulties were noted in the findings. According to the Historic Public Schools of Kansas (1992) report, $84 \%$ of the school districts in the state housed only one teacher. Consequently, they served only $19 \%$ of the total population, making attempts at equalizing services overwhelming. Also, the report stated that $55 \%$ of all the buildings housed only $16 \%$ of the total student population. Further, an interview with a school board member (Rausch, 1994) responsible for the integration of teachers met resistance from Black and White parents. Overall, the integration process influenced school zoning and the creation of neighborhood schools to give students access while reducing travel time. Rausch (1994) also insisted that the district was not re-zoned for racial purposes. Nonetheless, Rausch suggested that students' self-worth improved with desegregated schools, but academic quality and student learning outcomes did not demonstrate growth. 


\subsection{Teacher Preparation}

The level of teacher preparation has to be seen beyond the basic recital of school data by unpacking the relationship to culture of its times (Butts \& Cremin, 1953). Teacher preparation affects learning the most, and teacher quality is the most crucial factor in determining student learning and improving education (Eggen \& Kauchak, 2013; Hanushek et al., 2010; Rivkin et al., 1998; Sanders \& Rivers, 1996). The results showed that preparation planning began with the integration of teacher colleges and special schools (Saint Louis Board of Education, 1954). The K-12 public schools would integrate the following year, in September 1955. These plans were widely used during the first stages after the Brown (1954) decision ("Segregation end in high schools," 1954). Harris (for Whites) and Stowe Teacher Colleges (for Blacks) were the first public colleges in Missouri to establish plans for integration four months after the ruling. Upon the merger that was deemed successful, the American Council for Education established an Intergroup Education Program (Freeman, 1972) to assist with integration efforts and to facilitate collaborative learning experiences at all levels. The findings revealed that, despite collaborative efforts, Stowe had 10,000 fewer books and 37 fewer classrooms (Patterson, 1972). Also, among Harris faculty, $33 \%$ held a Ph.D., compared to $18 \%$ of faculty at Stowe Teacher College (Patterson, 1972). Additionally, Harris received accreditation from the North Central Association of Schools, and Stowe was not accredited (Patterson, 1972).

Furthermore, Ruth Harris (1967), the former president of the segregated Stowe Teachers College, reported that teachers' preparation would change alongside their roles in the community. She mentioned that teachers would not only focus on their classrooms but would guide children and support their families in adjusting socially and harmoniously, maximizing their shared spaces within their communities (Harris, 1967). In all, integration raised professional standards. To date, equality of educational opportunity can minimize the adverse effects of poverty when there is an intentional focus on the intersectionality of ability and diversity (Hoover, 2018). Berliner's (2006) findings that the teacher preparation process has to focus on professional knowledge (content expertise) and dispositions (professional behavior) are consistent with prior research.

The diversity that is present in today's classrooms man that educators cannot lack awareness of the cultural assets that students bring into the classroom. If there is any hope in closing the achievement gap teachers must be prepared to be equity-focused (Howard, 2020). Additionally, Grant and Hill (2020) assert that,

Well-established relationship between student motivational factors and engagement strategies would enable students to engage in authentic learning that may lead to educationally productive activities and increased motivation. Practitioners and researchers must focus on capturing and enhancing the visual representations of what students think about themselves, what their motivation is, and how they engage in meaningful activities. Perceptions are shaped by the learner's experiences and the environments in which they occur. Principles of development indicate that educators can influence experiences through the environment. ( $\mathrm{p}$. 48)

Teacher education reform movements is continuing to gain the attend of a vast bodies of scholars. Research suggest that teacher preparation move from a superficial approach to address DEI (Diversity, Equity and Inclusion) and the rhetoric towards grounded practices of multicultural education (Banks, 2004; Grant \& Sleeter, 2007; Nieto, 2000; Howard, 2010, 2016; Gay, 2005; Cole, 1998; Rogoff, 2003; Parham, 2002; Sleeter \& Bernal, 2004) that includes Culturally Sustaining Pedagogy (Paris, 2012).

\subsection{Situational Poverty}

The complexities of these issues highlight another theme: situational poverty. Situational poverty (Jensen, 2009) is caused by a crisis or loss. The time frame varies based on the impact of the event (i.e., environmental, legal, or political changes). Rosenthal (1957) noted that 82,000 Black teachers were employed nationally leading up to the 1954 Brown decision. Shortly after, the number of Black teachers decreased by 10,000 .

Gorski (2018) noted that living in poverty can cause lifelong effects and detrimental changes to the brain's development. Therefore, a student-centered, balanced learning environment with positive adult-student relationships can increase student achievement and improve their social-emotional lives. Conversely, the findings show that poverty discouraged the racial identity of Black teachers, and Black students minimized self-expression. Also, the loss of positions as teachers and principals forced many into poverty and out of their communities. Other findings echoed this sentiment (Cox, 1982; Fultz, 2004; Haney, 1978). Many teachers halted the dismal process by suing school districts. Nonetheless, the court costs could have devastated teachers. The findings also noted that Black teachers' displacement was inaccurately quantified (Fairclough, 2004). Another finding is that Black teachers preferred to teach middle-class children and discriminated against children with darker complexions, inferring that these children were of lower socioeconomic status (Fairclough, 2004). 
Student achievement was being diluted as teachers were being displaced.

The movement of White teachers who did not agree with integration or who were displaced due to the consolidation of schools has been associated with White flight. White flight refers to White families moving to the suburbs, where homeownership was prohibited for Black people (Pettigrew, 2004). Additionally, the cities they moved to did not suffer losses regardless of desegregation (Farley et al., 1980). This mobility and access to resources allowed White teachers to minimize conditions that lead to poverty and loss of employment. These findings unveil the possibility of second-generation segregation being closely linked to disgraced education (i.e., poor school outcomes, teacher quality, adequate facilities) and poverty. Beyond the role of desegregation, isolation from educational opportunities creates greater disparities and increases negative outcomes for African American students.

A major challenge exists when schools are trying to provide education to children in poverty. Research conducted by the National Center for Children in Poverty (2016) affirm that $21.2 \%$ of African-American children live in poverty as opposed to $8.7 \%$ of White children further amplifies the correlation between poverty, race, and educational achievement (sited in Yang \& Kobalt, 2018). To address these challenges, educators have to reframe their beliefs and own possibilities that children from disadvantaged backgrounds are capable of reaching academic excellence (Howard, 2020) despite the focus on improved clinical practice, (Hill, 2021) and the heightened attention being centered around trauma and (Adverse Childhood Experiences) ACEs.

\section{Discussion}

African-American students' education was lagging behind to a degree because White teachers were not trained in Culturally Relevant Teaching (Ladson-Billings, 1995) and the apparent cultural mismatch (Gay, 2000) contributed to the underachievement. Moreover, there teachers did not understand the communicative culture of the students to meet their academic needs of providing a high-quality education (Walker, 2018; Alexander, 2012). Their emotional overtones (Butts \& Cremin, 1953) impacted their ability to improve student learning outcomes for African American children in terms of lesson designs through a culturally responsive pedagogy (Banks, 1998; Gay, 2014; Howard, 2010; Ladson-Billings, 1995). Also, African American children's self-worth needed improvement. The educational disparities continue to persist and the disturbing testing data. The research from numerous scholars' report that Black student who are not faced with poverty are still performing at lower levels than their white counter parts. While the gap continues to exist, racial disparities are plaguing schools at even higher levels today than during the Brown Era (Weinberg, 1997; Low, 1982; Noguera, 2003; Gonzales et al., 2002; Takiki, 1993; Darling-Hammond, 2015).

To face challenges authentically, educators must understand culture (Butts \& Cremin, 1953, Howard, 2020; Banks, 2004). African American children were placed in the middle of social change, and Black teachers were highly trained and able to teach resilience within segregated schools (Walker, 2018). Their level of empathy and compassion was valuable to African American children because they wanted them to be a generation of educated people. However, their influence on the students impacted integration efforts, and Black teachers assumed that White teachers would not be willing to teach them. Thus, these children's educational opportunities were compromised. The groundwork for second-generation segregation was laid when African American community leaders were relegated to sup-par positions, and their status in the community was threatened. Equality of economic opportunity was minimized due to integration. The level of forced poverty increased as disgraceful educational practices emerged. Black teachers' contracts were not renewed as a result of integration, and uncertainty struck their communities.

Postponed educational opportunities remained in the policies and practices that followed the Brown (1954) decision. Desegregation seemed to demonstrate the moral and ethical standard of giving all people equal access to public facilities, but the unintended consequences were that consolidated schools and programs caused unemployment, as White families may not have wanted their children taught by Black teachers, even those with superior training and skill. The investigation showed that Lewin's theory could be used as a variable to measure the impact of a specific person in the situation (environment) and the predictability of the behavior that emerges from the conditions.

These examples from the work Estiaban-Guitart and colleagues (2019) encourage construction of a hybrid model of family and hegemonic culture linked to society,

so that a critical perspective, must be overcome, and efforts should be made towards educational models and practices that value, and indeed, guarantee, the survival of the different experiences, practices and life contexts of the learners, going beyond the typical assimilationist values and practices prevalent in schools, in which the curriculum, instruction, and teaching practices are often disconnected from the meaningful 
experiences, life contexts and practices of the learners. (p. 9)

Without culturally relevant pedagogies (Ladson-Billings, 2014) in schools, isolation from educational opportunities persists. Students from various ethnic groups and socioeconomic status do not have the opportunity to participate in a democratic classroom (Morrison, 2008; Wolk, 2003), and, therefore, do not develop an appreciation or value of different perspectives or cultures. Moreover, the K-12 educational setting may foster injustice, which leads to substantial consequences. Alexander (2012) reveals the school-to-prison pipeline projects 1 in 3 Black children and 1 in 6 Latino/x will go to prison, and teachers are critical resources linked to educational opportunities and social change.

The provision of separate but equal facilities did not settle the social contract and prevented cooperation. Systems preventing leaders from ensuring that wrongs are righted (Noguera et al., 2019) further perpetuates second-generation segregation through social and educational isolation. Because inequities can increase over time, early detection in the educational system is necessary. Thought leaders and system planners with the capacity to influence should develop a curriculum that integrates investigations into inequity with grade-level benchmarks aligned with policies and metrics (Chien et al., 2016; Reisberg \& Watson, 2010). Broadening participation in improving school-based experiences (Chowdry et al., 2008) results from the need to improve compulsory education and raise achievement levels.

There are many ways of reflecting on the Brown decision. "The elimination of legal segregation was a necessary step on the road toward racial justice. That the road is a long and difficult one should not blind us to the necessity and value of that very first step" (Jackson, 2000, p. 257). Nonetheless, this is an opportunity to examine the results of the past by acknowledging success as well as recognizing the future challenges that students and communities are preparing for. Guiner (2004) describes the damages from the Brown decision and writes,

The ambiguity of Brown's legacy is as much a consequence of interest divergence as of the temporary alliance between northern elites and civil rights advocates to promote social reform through biracial top-down cooperation grounded in the values of racial liberalism. The Court relied on incomplete data regarding the damage segregation did to the self-esteem of blacks while it underestimated the potentially negative impact of desegregation on the self-esteem of some blacks and perhaps inadvertently reinforced the identification of blackness with inferiority and stigma in the minds of whites. (p. 113)

The decision focused primarily on desegregation and, unfortunately, did not secure educational equality (Guiner, 2004). Since the offer and compromise of the case did not include educational opportunity, the ramification is second-generation segregation.

\subsection{Second-Generation Segregation}

In second-generation segregation, educational environments cause students to develop defeatist attitudes and lowered educational aspirations (Zirkel \& Cantor, 2004). Disproportionate levels of suspension and expulsion and the fact that the criminal justice system assigns criminal labels to children of color are not a new (Children's Defense Fund, 1975; McCarthy \& Hoge, 1987; Skiba et al., 1997; Skiba et al., 2002; Thornton \& Trent, 1988). Institutions' continued use of this practice ushers in second-generation segregation, which legalizes the denial of educational opportunities (Alexander, 2012). Social contracts should display justice as fairness (Rawls, 1971), and, when they do not, racial disproportionality amplifies and encourage schools to institute negative consequences as a management style, contributing to the social isolation of children of color.

Moreover, to question and to invite conversation is not to doubt the intention or the results of the Brown decision to make the world more just and equal or the federal guidelines to integrate schools. Segregation, regardless of circumstances, had deprived minority children of equal educational opportunities and probably generated feelings of inferiority among them. Comparatively, something is not quite right, and society seems to be moving away from a commitment to school integration by imposing constraints on operations and organizations (Orfield, 2001; Orfield \& Eaton, 1996). The call here is for a redistribution of power and for fundamental systemic change to transcend the disproportionality plaguing students of color in terms of suspension and expulsion rates, which adversely affect their educational opportunities and economic trajectories. Given the the social science and critiques discussed here, revisionary history is possible (Zirkel \& Cantor, 2004).

The connection between education and social justice becomes fractured when institutions have drastically different outcomes. Bottia and colleagues (2015) stated that "all social systems create mechanisms for distributing valued resources and allocating rights, responsibilities, costs, and burdens" (p. 42). Currently, racial exclusion and discrimination manifest through a form of legalized segregation in education. Having received relatively little attention, second-generation segregation is occurring through language acquisition programs 
shifting racial dispartieis past the binary understanding of Black and White(Parham, 2002; Gay, 2000; Howard, 2020) to include LatinX, Native-American, and specific Asian-American communities. Moreover, students are being placed in English as a second language courses, restricting their access to honors and Advanced Placement classes and lowering college and career readiness. Students of color are experiencing resegregation.

\section{Implications}

To bring together the themes and to take this case study across programs, we must agree that we can develop intercultural competence to address systems of racism. The assumption implied by the Brown ruling is a standard of reasonableness that should address issues critical to race and education. The APA Taskforce (2012) acknowledged the psychological impact of segregation and implied a need to address this impact.

However, the Court could not have anticipated social justice matters this far in advance: the considerable complexity of segregation and its impact on students of color. Thus, education must be evaluated in the present and in light of the effects of segregation (Rawls, 1971). A critical consciousness, defined by Freire (2000) as the process by which we apply critical thinking skills to examine our current situations, leads to a deeper understanding of our concrete reality to devise, implement, and evaluate solutions to problems. Students do not develop these skills when they are isolated from educational opportunities in the classroom and society. Developing cultural diversity in the classroom is a key indicator of academic achievement (Esteban-Guitart et al., 2019). Additionally, the intercultural development inventory (IDI) provides interpretations to increase educators' cultural awareness by understanding orientations resulting from cultural interactions (Hammer \& Bennett, 2003). Understand the prevalence, impact and implications of second-generation segregation requires more research on the intersections of intercultural development and effective teaching. The figures below show the continuum of developmental areas of culture, the orientations, and their meanings.

\section{Intercultural Development Continuum}

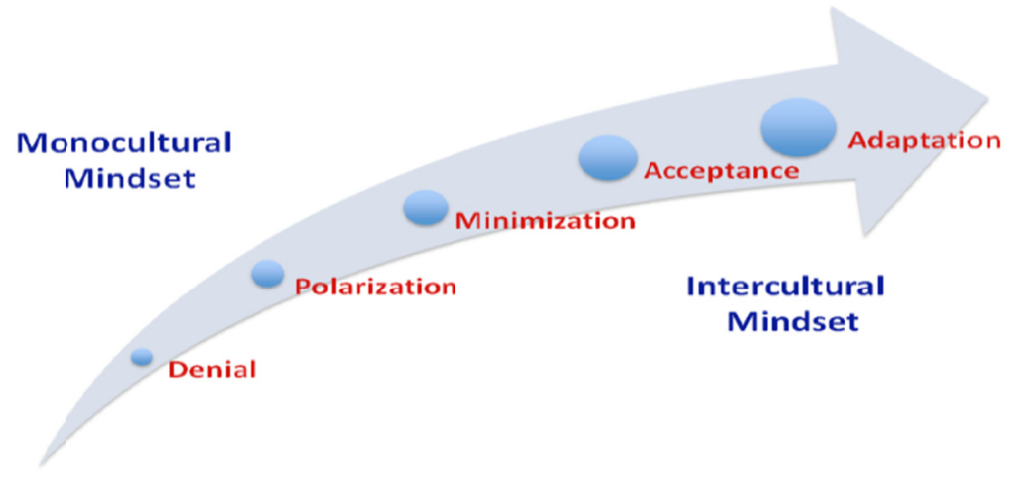

Figure 5. Intercultural development continuum

Note. Used with permission.

Table 2. Summary of orientation descriptions

\begin{tabular}{ll}
\hline Terms & Descriptions \\
\hline Denial & $\begin{array}{l}\text { An orientation that likely recognizes more observable cultural differences (e.g., food) but may not notice deeper cultural } \\
\text { difference (e.g., conflict resolution styles) and may avoid or withdraw from cultural differences. }\end{array}$ \\
Polarization & A judgmental orientation that views cultural differences in terms of "us" and "them." This can take the form of: \\
Defense & An uncritical view toward one's own cultural values and practices and an overly critical view toward other cultural values and \\
& practices. \\
Reversal & $\begin{array}{l}\text { An overly critical orientation toward one's own cultural values and practices and an uncritical view toward other cultural values } \\
\text { and practices. }\end{array}$ \\
Minimization & An orientation that highlights cultural commonality and universal values and principles that may also mask deeper recognition \\
Acceptance & and appreciation of cultural differences. \\
Adaptation & An orientation that recognizes and appreciates patterns of cultural difference and commonality in one's own and other cultures. \\
& ways.
\end{tabular}

Note. Used with Permission 


\section{Conclusion}

The research on the effects of racial composition and achievement suggests "many desegregation plans ordered by courts were accompanied by conflict and resistance so that most short-run investigations of the impact of integration on achievement are contaminated by factors related to the desegregation process" (Hanushek et al., 2001, p. 11). Friske (1993) defines new racism as a struggle over the power to promote social interest that are always racialized (quoted in Cross, 2005, p. 267) Since racism is not being perpetuated physically as much, but is rather done by well-intentioned people in society through structures established by the dominant group (McLaren, 2007). The right to choose any school through an open enrollment process was considered a rationale behind school segregation, which still occurs today. Similarly, the mobility and quality of resources effects noted during the Brown decision are distorting parent and community expectations about student success (Reardon \& Owens, 2014).

The diluted levels of achievement that African-American students experienced are a result of an effective desegregation plan, leading to the Spangler (1976) decision. The hidden provocateurs were the Black educators who advocated for adequate resources (Walker, 2018). Jim and Nancy Spangler (1976) are hidden provocateurs in their own right through their display of moral courage in addressing racial imbalance at all levels of the school system. The ruling affirmed that hiring and promotion, staff assignments, and facilities should be included in the desegregation plan to realize a truly integrated system with equality of opportunity and participation in the decision-making process.

In light of the informative decision, the National Collaborative on Diversity in Teacher Education (2004) affirms the recommendation to recruit and retain a more diverse teaching force and establish expectations to influence the well-being of all students. Transforming the teaching profession and placing those individuals who serve in a place of honor is essential to creating an effective desegregation plan, will prevent the further postponement of educational opportunities, and will minimize the harm to our future (Frankenberg et al., 2019).

This critical piece can improve student's performance and academic achievement through IDI and the Teaching and Learning Inventories (TLI) inventories. Additionally, the increased need for anti-biased education to combat second-generation segregation and improve educational outcomes for black students is essential. The four goals of anti-bias education are

- Each child will demonstrate self-awareness, confidence, family pride, and positive social identities.

- Each child will express comfort and joy with human diversity; accurate language for human differences; and sincere, caring human connections.

- Each child will increasingly recognize unfairness, have the language to describe unfairness, and understand that unfairness hurts.

- Each child will demonstrate empowerment and the skills to act, with others or alone, against prejudice and discrimination. (Grant \& Hill, 2020, p. 49)

These added dimension gives the students confidence and motivation that builds on a strong teacher-student relationship and improves literacy (Sealey-Ruiz, 2013). Moreover, monitoring teacher quality to ensure teachers are equipped with the skills to improve learning outcomes and develop cultural competence will change students' trajectories. One would think that if the desegregation plan was for Black and White teachers to work in the same classrooms to support integration, diversity equality, and inclusion students would not be in an era of second-generation segregation. In other words, to better understand the complexities for culture and race state education agencies could have potentially encouraged interracial collaboration over negative competition. Reflecting on issues that persist produces effective questioning, which opens the door to possibilities.

\section{References}

Alexander, M. (2012). The new Jim Crow: Mass incarceration in the age of colorblindness (Revised ed.). New Press.

Annamma, S., Ferri, B., \& Connor, D. (2018). Disability critical race theory: Exploring the intersectional lineage, emergence, and potential futures of DisCrit in education. Review of Research in Education, 42(1), 46-71. https://doi.org/10.3102/0091732X18759041

Bandura, A. (1982). Self-efficacy mechanism in human agency. American Psychologist, 37(2), 122-147. https://doi.org/10.1037/0003-066X.37.2.122

Banks, J. (1994). Multiethnic education: Theory and practice (3rd ed.). Allyn \& Bacon. 
Baxter, P., \& Jack, S. (2008). Qualitative case study methodology: Study design and implementation for novice researchers. Qualitative Report, 13(4), 544-559. Retrieved from http://www.nova.edu/ssss/QR/QR13-4/baxter.pdf

Berliner, D. C. (2006). Educational psychology: Searching for essence throughout a century of influence. In P. Alexander \& P. Winne (Eds.), Handbook of educational psychology (2nd ed., pp. 3-27). Erlbaum.

Bottia, M. C., Giersch, J., Mickelson, R. A., Stearns, E., \& Moller, S. (2016). Distributive justice antecedents of race and gender disparities in first-year college performance. Social Justice Research, 29(1), 35-72. https://doi.org/10.1007/s11211-015-0242-x

Brown v. Board of Education of Topeka, 347 U.S. 483 (1954).

Bushaw, W., \& Lopez, S. (2010). A time for change: The 42nd Annual Phi Delta Kappa/Gallup Poll of the public's attitudes toward the public schools. Phi Delta Kappan, 92, 8-26. https://doi.org/10.1177/003172171009200103

Carroll, J. (2014, October 18). Race and Education 50 Years After Brown v. Board of Education. Retrieved January 24, 2021, from https://news.gallup.com/poll/11686/race-education-years-after-brown-board-education.aspx

Chien, C.-L., Montjourides, P., \& van der Pol, H. (2016). Global trends in access to post-secondary education. In A. Mountford-Zimdars (Ed.), Access to higher education: Theoretical perspectives and contemporary challenges (pp. 3-32). Taylor \& Francis/Routledge.

Children's Defense Fund. (1975). School suspensions: Are they helping children? Washington Research Project.

Chowdry, H., Crawford, C., Dearden, L., Goodman, A., \& Vignoles, A. (2008). Understanding the determinants of participation in higher education and the quality of institute attended: analysis using administrative data. Institute of Fiscal Studies. Retrieved from http://www.ifs.org.uk/publications.php?publication_id=4234

College Board. (2018). 2018 Total group SAT suit of assessment annual report. Retrieved from https://reports.collegeboard.org/pdf/2018-total-group-sat-suite-assessments-annual-report.pdf

Cox, T. C. (1982). Blacks in Topeka, Kansas 1865-1915: A social history. Louisiana State University Press.

Cross, B. E. (2005). New Racism, Reformed Teacher Education, and the Same Ole' Oppression. Educational Studies, 38, 263-274. https://doi.org/10.1207/s15326993es3803_6

Darling-Hammond, L. (2010). Teacher education and the American future. Journal of Teacher Education, 61(1-2), 35-47. https://doi.org/10.1177/0022487109348024

Darling-Hammond, L. (2015). Can value added add value to teacher evaluation? Educational! Researcher, 44(2), 132-137. https://doi.org/10.3102/0013189X15575346

DuBois, W. E. B. (1935). Does the Negro need separate schools? The Journal of Negro Education, 4(3), 328-335. https://doi.org/10.2307/2291871

Eggen, P., \& Kauchak, D. (2013). Educational psychology: Windows on classrooms (9th ed.). Pearson Education.

Esteban-Guitart, M., Lalueza, J. L., Zhang-Yu, C., \& Llopart, M. (2019). Sustaining students' cultures and identities. A qualitative study based on the funds of knowledge and identity approaches. Sustainability, 11(12), 3400. https://doi.org/10.3390/su11123400

European-American Collaborative Challenging Whiteness. (2005). Critical humility in transformative learning when self-identity is at stake. In D. Vlosak, G. Kielbaso \& J. Radford (Eds.), Appreciating the best of what is: Envisioning what could be (pp. 121-126). Proceedings of the Sixth International Conference on Transformative Learning. Michigan State University.

Fairclough, A. (2004). The costs of Brown: Black teachers and school integration. The Journal of American History, 91(1), 43-55. https://doi.org/10.2307/3659612

Farley, R., Richards, T., \& Werdock, C. (1980). School desegregation and white flight: An investigation of competing models and their discrepant findings. Sociology of Education, 53, 123-139. https://doi.org/10.2307/2112408

Ferri, B. A., \& Connor, D. J. (2005). Tools of exclusion: Race, disability, and (re)segregated education. Teachers College Record, 107(3), 453-474. https://doi.org/10.1111/j.1467-9620.2005.00483.x 
Fiske, S. T. (1993). Controlling other people: The impact of power on stereotyping. American Psychologist, 48(6), 621-628. https://doi.org/10.1037/0003-066X.48.6.621

Flyvbjerg, B. (2006). Five misunderstanding about case-study research. Qualitative Inquiry, 12(2), 219-245. https://doi.org/10.1177/1077800405284363

Frankenberg, E., Ee, J., Ayscue, J. B., \& Orfield, G. (2019). Harming our common future: America's segregated schools 65 years after Brown. Civil Rights Project.

Freeman, R. R., Jr. (1972). The St. Louis public schools, 1938-1956, with emphasis on Philip J. Hickey, Superintendent, 1942-1956: A study of the school board-superintendent relationship (Publication No. 735037). Doctoral Dissertation. Washington University, St. Louis, MO, United States.

Freire, P. (2000). Pedagogy of the oppressed. Continuum.

Fultz, M. (2004). The displacement of Black Educators Post-Brown: An overview and analysis. History of Education Quarterly, 44(1), 11-45. https://doi.org/10.1111/j.1748-5959.2004.tb00144.x

Gay, G. (2000). Culturally responsive teaching: Theory, research, and practice. New York: Teachers College Press.

Gay, G. (2005). Standards of diversity. In S. P. Gordon (Ed.), Standards for instructional supervision: Enhancing teaching and learning (pp. 107-120). Larchmont, NY: Eye on Education. https://doi.org/10.4324/9781315855301-10

Gay, G. (2014). Culturally responsive teaching principles, practices, and effects. In H. R. Milner \& K. Lomotey (Eds.), Handbook of Urban Education (pp. 253-372). Routledge.

Gibson, J. J. (1977). The concept of affordances. In R. Shaw \& J. Bransford (Eds.), Perceiving, acting, and knowing: Toward an ecological psychology (pp. 67-82). Lawrence Erlbaum.

Goldstein, D. (2015). The teacher wars: A history of America's most embattled profession. Doubleday.

Gonzales, P. M., Hart, B., \& Williams, J. (2002). The Effects of Stereotype Threat and Double-Minority Status on the Test Performance of Latino Women. Personality and Social Psychology Bulletin, 28, 659-670. https://doi.org/10.1177/0146167202288010

Gorski, P. (2018). Reaching and teaching students in poverty: Strategies for erasing the opportunity gap (2nd ed.). New York, NY: Teachers College Press.

Grant, C. A., \& Sleeter, C. E. (2007). Doing multicultural education for achievement and equity. New York: Routledge.

Grant, D., \& Hill, J. B. (2020). Activating Culturally Empathic Motivation in Diverse Students. Journal of Education and Learning Journal of Education and Learning, 9(5), 45-58. https://doi.org/10.5539/jel.v9n5p45

Guinier, L. (2004). From racial liberalism to racial literacy: Brown v. Board of Education and the interest-divergence dilemma. The Journal of American History, 91(1), 92. Advance online publication. https://doi.org/10.2307/3659616

Hammer, M. R., Bennett, M. J., \& Wiseman, R. (2003). Measuring intercultural sensitivity: The intercultural development inventory. International Journal of Intercultural Relations, 27(4), 421-443. https://doi.org/10.1016/S0147-1767(03)00032-4

Hanushek, E., Kain J., \& Rivkin, S. (2009). New evidence about Brown v. Board of Education: The complex effects of school racial composition on achievement. Journal of Labor Economics, 27(3), 349-383. https://doi.org/10.1086/600386

Harris, R. M. (1967). Stowe Teachers College and her predecessors. Christopher.

Hess, C., Gabriel, R., Leibbrand, C., \& Crowder, K. (2019). Does hypersegregation matter for Black-white socioeconomic disparities? Demography, 56(6), 2169-2191. https://doi.org/10.1007/s13524-019-00825-y

Hill. J. B. (2021). Pre-Service Teacher Experiences during COVID 19: Exploring the Uncertainties between Clinical Practice and Distance Learning. Journal of Practical Studies in Education, 2(2), 1-13. https://doi.org/10.46809/jpse.v2i2.18

Hoover, J. J. (2018). Exceptionality, diversity, and educator preparation: Overview of the topical issue. Teacher Education and Special Education, 41, 173-175. https://doi.org/10.1177/0888406418774103 
Howard, T. C. (2010). Why race and culture matter in schools: Closing the achievement gap in America's classrooms. Teachers College Press.

Howard, T. C. (2016). Why Black Lives (and Minds) Matter: Race, Freedom Schools \& the Quest for Educational Equity. The Journal of Negro Education, 85(2), 101-113. https://doi.org/10.7709/jnegroeducation.85.2.0101

Howard, T. C. (2020). Why Race and Culture Matter in Schools: Closing the Achievement Gap in America's Classrooms (2nd ed.). United States: Teachers College Press.

Irvine, J. J. (2003). Educating teachers for diversity: Seeing with a cultural eye. New York: Teachers College Press.

Jackson, C. (1991, September 20). Interviewed by VanDelinder, J. \& Crowder, R. [Audio Recording]. Kansas State Historical Society Oral History Project, Brown v. Board of Education. Retrieved from https://www.kansasmemory.org/item/211835

Jackson, J. P., Jr. (2000). The triumph of the segregationists? A historiographical inquiry into psychology and the litigation. History of Psychology, 3, 239-261. https://doi.org/10.1037/1093-4510.3.3.239

Jiang, Y., \& Koball, H. (2018). Basic Facts about Low-Income Children: Children under 18 Years, 2016. New York: National Center for Children in Poverty, Columbia University Mailman School of Public Health. Retrieved from https://www.nccp.org/wp-content/uploads/2018/01/text_1194.pdf

Johnson, R. C. (2011). Long-run impacts of school desegregation \& school quality on adult attainments (Paper No. 16664). National Bureau of Economic Research. https://doi.org/10.3386/w16664

Kluger, R. (1976). Simple justice: The history of Brown v. Board of Education and Black America's struggle for equality. Alfred A. Knopf.

Ladson-Billings, G. (1995). Toward a theory of culturally relevant pedagogy. American Educational Research Journal, 32, 465-491. https://doi.org/10.3102/00028312032003465

Ladson-Billings, G. (2006). It's not the culture of poverty, it's the poverty of culture: The problem with teacher education. Anthropology \& Education Quarterly, 37(2), 104-109. https://doi.org/10.1525/aeq.2006.37.2.104

Ladson-Billings, G. (2014). Culturally relevant pedagogy 2.0: The remix. Harvard Educational Review, 84(1), 74-84. https://doi.org/10.17763/haer.84.1.p2rj131485484751

Lewin, K. (1936). Principles of topological psychology. McGraw Hill. https://doi.org/10.1037/10019-000

Low, V. (1982). The Unimpressible Race: A Century of Educational Struggle by the Chinese in San Francisco. San Francisco: East/West Publishing Company.

Madkins, T. C. (2011). The Black teacher shortage: A literature review of historical and contemporary trends. The Journal of Negro Education, 80(3), 417-427, 437.

Marzano, R. J. (2009). Designing \& teaching learning goals \& objectives. Bloomington, IN: Marzano Research Laboratory.

McCarthy, J. D., \& Hoge, D. R. (1987). The social construction of school punishment: Racial disadvantage out of universalistic process. Social Forces, 65, 1101-1120. https://doi.org/10.1093/sf/65.4.1101

McLaren, P. (2007). Life in schools: An introduction to critical pedagogy in the foundations of education. Boston: Pearson/Allyn and Bacon.

Meier, K. J., Stewert, J. J., \& England, R. E. (1989). Race, class, and education: The politics of second-generation discrimination. Madison, WI: University of Wisconsin Press.

Mickelson, R. (2001). Subverting Swann: First- and Second-Generation Segregation in the Charlotte-Mecklenburg Schools. American Educational Research Journal, 38, 215-252. https://doi.org/10.3102/00028312038002215

Mickelson, R. (2015). The Cumulative Disadvantages of First- and Second-Generation Segregation for Middle School Achievement. American Educational Research Journal, 52, 657-692. https://doi.org/10.3102/0002831215587933

Morrison, K. A. (2008). Democratic classrooms: Promises and challenges of student voice and choice, part one. Educational Horizons, Fall 2008, 50-60. 
$\begin{array}{llllll}\text { National Center for } & \text { Education } & \text { Statistics. } & \text { (2013). } & \text { Retrieved }\end{array}$ https://nces.ed.gov/programs/coe/indicator_cnj.asp

National Collaborative on Diversity in Teacher Education. (2004). Assessment of Diversity in America's Teaching Force.

Noguera, P. A. (2003). City schools and the American dream: Reclaiming the promise of public education. Teachers College Press.

Oakes, J. (2005). Keeping track: How schools structure inequality (2nd ed.). New Haven, CT: Yale University Press.

Orfield, G. (2001, July). Schools more separate: Consequences of a decade of resegregation. Retrieved from http://www.law.harvard.edu/civilrights/publications

Orfield, G., \& Eaton, S. E. (1996). Dismantling desegregation: The quiet reversal of Brown v. Board of Education. The New Press.

Parham, T. A. (Ed.). (2002). Multicultural aspects of counseling series (Vol. 18. Counseling persons of African descent: Raising the bar of practitioner competence). Sage Publications, Inc.

Paris, D. (2012). Culturally sustaining pedagogy: A needed change in stance, terminology, and practice. Educational Researcher, 41(3), 93-97. https://doi.org/10.3102/0013189X12441244

Patterson, R. H. (1972). Harris Teachers College: 1904-1966 (Publication No. 7223994). Doctoral dissertation. Saint Louis University, St. Louis, MO, United States.

Pettigrew, T. (2004). Justice deferred: A half century after Brown v. Board of Education. The American Psychologist, 59(6), 521-529. https://doi.org/10.1037/0003-066X.59.6.521

Rausch, F. (1994, October 12). Interview by Brown, C. [Audio Recording]. Kansas State Historical Society Oral History Project, Brown v. Board of Education. Retrieved from https://www.kansasmemory.org/item/211837

Rawls, J. (1971). A theory of justice. Belknap Press.

Reardon, S. F., \& Owens, A. (2014). 60 Years After Brown: Trends and Consequences of School Segregation. https://doi.org/10.1146/annurev-soc-071913-043152

Reisberg, L., \& Watson, D. (2010). Access and Equity. In Leadership for world-class universities. Challenges for developing countries (pp. 187-204). Boston College. Retrieved from http://www.gr.unicamp.br/ceav/revista/content/pdf/Watson_Reisberg-Access_and_Equity_en.pdf

Rivkin, S. G., Hanushek, E. A., \& Kain, J. F. (1998). Teachers, schools and academic achievement. Econometrica, 73(2), 417-458. https://doi.org/10.1111/j.1468-0262.2005.00584.x

Rogoff, B. (2003). The cultural nature of human development. Oxford, UK: Oxford University Press.

Rosenthal, J. O. (1957). Negro teachers' attitudes toward desegregation. The Journal of Negro Education, 26(1), 63-71. https://doi.org/10.2307/2293328

Saint Louis Board of Education. (1954). Official proceedings of the board of education of the city of St. Louis (Vol. LX).

Sanders, W. L., \& Rivers, J. C. (1996). Cumulative and residual effects of teachers on future student academic achievement. University of Tennessee Value-Added Research and Assessment Center.

Saunders, W., \& Goldenberg, C. (2010). Improving education for English learners. California Department of Education.

Sealey-Ruiz, Y. (2013). Toward a pedagogy of racial literacy in first year composition. Teaching English in the Two-Year College, 40(3), 384-398.

Skiba, R. J., Michael, R. S., Nardo, A. C., \& Peterson, R. L. (2002). The color of discipline: Sources of racial and gender disproportionality in school punishment. The Urban Review, 34(4), 317-342. https://doi.org/10.1023/A:1021320817372

Skiba, R. J., Peterson, R. L., \& Williams, T. (1997). Office referrals and suspension: Disciplinary intervention in middle schools. Education \& Treatment of Children, 20(3), 295-315.

Sleeter, C., \& Bernal, D. (2004). Critical pedagogy, critical race theory, and antiracist education: Implications for multicultural education. In J. A. Banks \& C. A. McGee Banks (Eds.), Handbook of research on 
multicultural education (2nd ed., pp. 240-258). New York: Macmillan.

Spangler v. Pasadena City Bd. of Educ., 375 F. Supp. 1304 (C.D. Cal. 1974), aff'd, 519 F.2d 430 (9th Cir. 1975), rev'd, 427 U.S. 424 (1976).

Stake, R. E. (1995). The art of case study research. Sage.

Steen, S., \& Noguera, P. A. (2010). A broader and bolder approach to school reform: Expanded partnership roles for school counselors. Professional School Counseling, 14(1), 42-52. https://doi.org/10.5330/prsc.14.1.puq62087h7q70801

Strauder v. West Virginia, 100 U.S. 303, 307-308 (1880)

Supreme Court of The United States. (1872). U.S. Reports: Slaughter-House Cases, 83 U.S. 16 Wall. 36. Library of Congress. Retrieved from https://www.loc.gov/item/usrep083036/

Takaki, R. (1989). Strangers from a Different Shore. New York: Little, Brown.

Thornton, C. H., \& Trent, W. (1988). School desegregation and suspension in East Baton Rouge Parish: A preliminary report. The Journal of Negro Education, 57, 482-501. https://doi.org/10.2307/2295691

Tushnet, M. V. (1987). The NAACP's legal strategy against segregated education, 1925-1950. University of North Carolina Press. https://doi.org/10.5149/uncp/9780807855959

$\begin{array}{lllll}\text { U.S. Department } & \text { of } & \text { (2017). } & \text { Retrieved }\end{array}$ https://nces.ed.gov/programs/raceindicators/indicator_rad.asp

Vergara v. California. (2014). Case No. BC484642. Retrieved from http://studentsmatter.org/wpcontent/uploads/2014/06/Tenative-Decision.pdf

Walker, V. S. (2018). The lost education of Horace Tate: Uncovering the hidden heroes who fought for justice in schools.

Weinberg, M. (1997). Asian-american Education: Historical Background and Current Realities.

Wilson, P. E. (1953). Letter to T. Justin Moore. 10 June 1953. Box 1, Folder 2. DaRT ID: 211845. Records of the Attorney General's Office, Brown v. Board Files. Retrieved from http://www.kansasmemory.org/item/211845

Wolk, S. (2003). Teaching for Critical Literacy in Social Studies, The Social Studies, 94:3, 101-106

Yin, R. K. (2003). Case study research: Design and methods (3rd ed.). SAGE.

Zirkel, S., \& Cantor, N. (2004). 50 years after Brown v. Board of Education: The Promise and challenge of multicultural education. The Journal of Social Issues, 60(1), 1-15. https://doi.org/10.1111/j.0022-4537.2004.00096.x

\section{Copyrights}

Copyright for this article is retained by the author, with first publication rights granted to the journal.

This is an open-access article distributed under the terms and conditions of the Creative Commons Attribution license (http://creativecommons.org/licenses/by/4.0/). 